A practitioner's guide to the design of strategy map frameworks

\author{
Syrus Islam
}

\title{
Auckland University of Technology
}

New Zealand

syrus.islam@aut.ac.nz

This version: January 2018

Please cite this document as follows:

Syrus Islam, (2018) "A practitioner's guide to the design of strategy map frameworks", Pacific Accounting Review, Vol. 30 Issue: 3, pp.334-351, 


\section{A practitioner's guide to the design of strategy map frameworks}

\section{Structured Abstract}

Purpose - The objective of this study is to synthesise the prior literature on strategy maps in order to develop a practitioner's guide to the design of strategy map frameworks. Robert Kaplan and David Norton introduced the strategy map in their 2000 Harvard Business Review article. A strategy map visually represents how the critical elements of an organisation's strategy are linked together. In an organisation's strategy execution process, a strategy map complements a performance measurement system such as the balanced scorecard.

Design/methodology/approach - This is a technical paper, which primarily builds on the prior literature on the strategy map design. In particular, this study reviews 41 publications on strategy maps in the period 2000 - 2015, including 333 strategy map frameworks.

Findings - This study develops 14 design principles across seven features of a strategy map framework. This study also identifies a significant lack of empirical research on strategy map design features and principles.

Research implications - Future research could examine whether and why various design features and principles could exert different or same effects (e.g., decision-relevance).

Practical implications - The developed design features and principles can be used by practitioners as guidance for developing customised strategy maps for their organisations.

Originality/value - This paper contributes to the literature by serving as a 'one-stop-shop' for both practitioners and researchers seeking a comprehensive understanding of the current state of strategy map design features and principles.

Keywords: Strategy maps; Design features and principles; Balanced scorecard; Performance measurement; Practitioners; Literature review

Paper type Technical paper 


\section{Introduction}

The balanced scorecard (BSC) developed by Kaplan and Norton (1992) is a popular performance measurement system (PMS), but it does not provide a coherent understanding of an organisation's 'strategy story' (Kaplan and Norton, 2004b). To communicate the organisation's strategy story succinctly amongst the employees, and, thereby, better execution of strategy, Kaplan and Norton (2000) introduced the strategy map. A strategy map complements a PMS in an organisation's strategy execution process (Kaplan and Norton, 2004b). This is also supported by recent research. For example, Banker et al. (2011) show that the presence of temporally separated measures (i.e., leading and lagging indicators) in a BSC and non-linear relations inherent in non-financial metrics create significant cognitive demand on experimental subjects' working memory, and the strategy map reduces that cognitive demand by improving knowledge organisation.

A strategy map is now considered as one of the most recommended management tools for strategy execution [1]. Evidence of strategy maps' use is also well-documented in different organisational sectors - commercial, government, and not-for-profit (Chan, 2009; Cugini et al., 2011; Kaplan and Norton, 2004b, 2006a, 2008a). Strategy maps have also generated interests in the academic community, where researchers have identified a number of benefits of their use, such as advancing decision-making ability within a strategic context (Banker et al., 2011; Banker et al., 2004), enhancing employees' ability to understand complex phenomena (Vera-Muñoz et al., 2007), and facilitating managers' ability to filter irrelevant information (Cheng and Humphreys, 2012).

However, to date, there is no comprehensive study on design features and principles of strategy map frameworks that could serve as a 'one-stop-shop' for strategy map design features and principles. The current study aims to fill this void in the literature. A comprehensive understanding of strategy map design features and principles is important. Recent research suggests that on the one hand, a well-designed strategy map can counter short-term financial bias; on the other hand, an inappropriately designed strategy map may encourage employees to pursue disjointed actions (Lowe et al., 2011). Further, every organisation is unique with different strategies. Even if two organisations pursue the same goal (e.g., increase cash flow), there are many different ways to attain that goal. As a strategy map intends to clearly communicate an organisation's strategy and show how it will be achieved (Kaplan and Norton, 2001a, 2004b), a generic strategy map framework may not be suitable for all organisations. 
Therefore, a comprehensive understanding of strategy map design features and principles can help managers design a customised strategy map framework, considering their organisations' unique contexts.

This study develops 14 principles across seven features for designing a strategy map framework. This article contributes to the literature by serving as a 'one-stop-shop' for both practitioners and researchers seeking a state-of-the-art overview of strategy map design features and principles. In so doing, this study also responds to the recent call for more research on strategy maps, where so far researchers have paid little attention (Cheng and Coyte, 2014; Hoque, 2014).

The paper is structured as follows. The next two sections detail the methods and a brief discussion of context and benefits of strategy maps. The fourth section then presents strategy map design features and principles developed in this study. The final section provides concluding comments and offers avenues for future research.

\section{Methods}

Given the aim of this study, publications having a reasonable focus on strategy maps were located in two stages. First, as Kaplan and Norton introduced the strategy map, a search was conducted for all their major publications on strategy maps, which resulted in 11 publications (see Appendix A).

Second, strategy map publications were searched in 25 highly ranked accounting journals and 46 highly ranked business and management journals, which were also used by Hoque (2014, pp. 50-51). Further, Google Scholar was used to locate additional publications on strategy maps. The search used the term "strategy map" and continued until the end of 2015. The initial results revealed several articles, which were downloaded and examined for reasonable insights and experiences related to strategy maps. This resulted in 30 publications (see Appendix A).

Overall, to develop strategy map design features and principles, 41 publications on strategy maps were examined, including 333 strategy map frameworks (see Appendix A). Further, general accounting, management, and psychology literature were consulted.

\section{The strategy map, its context, and benefits}


The BSC developed by Kaplan and Norton (1992) has become one of the most popular PMSs (Atkinson et al., 1997; Langfield-Smith, 2005). Although Kaplan and Norton (2001b) originally developed the BSC as a tool to measure organisational performance, within few years, they found that many organisations were using it to implement their strategies. They also found that in the majority of failed cases, the real problem lies not in bad strategy, but in its bad execution (Kaplan and Norton, 2004b). To aid the better execution of strategy, they subsequently introduced the strategy map (Kaplan and Norton, 2000).

A strategy map is a "logical and comprehensive architecture for describing strategy" and it "specifies the critical elements and their linkages for an organisation's strategy" (Kaplan and Norton, 2001b, p. 90). It is well-established that an organisation's PMS should be built in alignment with its strategy to better implement the strategy (e.g., Adler, 2011; Chenhall, 2005; Kaplan, 2009; Langfield-Smith, 2005). A strategy map facilitates this process. A strategy map visually represents what would be the relation amongst strategic objectives and how they will deliver the strategy (Kaplan and Norton, 2001a). Then for each strategic objective, organisations can develop appropriate performance metrics and performance targets in their PMSs (Kaplan and Norton, 2004b). Consequently, strategy maps are considered a crucial tool for strategy implementation and are used along with a PMS (Kaplan and Norton, 2001a, 2004b).

Prior experimental research documents several benefits of using strategy maps. For example, Banker et al. (2004) found that in evaluating strategic business unit performance when decision-makers are provided with a strategy map as well as strategy narratives, they make decisions more consistent with strategic objectives. In a subsequent experiment, Banker et al. (2011) found that providing only narrative (but not the strategy map) reduces that ability of decision-makers. It shows that strategy maps play a vital role to facilitate decision making within a strategic context. In another study, Vera-Muñoz et al. (2007) found that a strategy map reduces accountants' cognitive difficulty and improves their ability to understand and manage the complex relations amongst performance metrics in a PMS. Similarly, Tayler (2010) showed that a strategy map can help managers to focus on activities that are the most critical to their organisations' success.

Recent research shows that strategy maps can eliminate common measure bias or financial fixation (Humphreys and Trotman, 2011) and facilitate a cogent communication of the organization's goals and strategy, which is crucial to employee 'buy-in' to achieve those goals 
and strategy (Lowe et al., 2011). Farrell et al. (2012) show that communication through strategy maps significantly improves employees' effort and firm performance. Similarly, Cheng and Humphreys (2012) find that strategy maps enhance managers' ability to differentiate relevant and irrelevant external information with respect to a firm's strategy.

\section{Design features and principles of strategy map frameworks}

A total of 14 design principles are developed around seven features of strategy map frameworks. Principles are presented below under each of the seven features.

\subsubsection{Strategy, mission, and vision}

Principle 1: A strategy map needs to incorporate strategy, mission, and/or vision statement

Generally, organisations put strategy, mission, and vision at the very top of their strategy maps, but not all organisations mention all three. Some organizations mention only a strategy statement (e.g., Kaplan and Norton, 2004b, p. 221); some others mention only a mission statement (e.g., Kaplan and Norton, 2004b, p. 432); some others mention only a vision statement (e.g., Kaplan and Norton, 2004b, p. 159); and some others mention a combination of the three (e.g., Kaplan and Norton, 2004b, p. 314). As those three terms communicate a closely related (but not exactly the same) high-level message of the organisation as a whole (Collis and Rukstad, 2008; Kaplan and Norton, 2008b), organisations may use any combination of the three.

However, some strategy map frameworks observed (see Joseph and George, 2011, p. 10; Rompho, 2012, p. 59) have not mentioned any of the three. This practice is flawed. The ultimate objective of a strategy map is to clearly communicate and thereby, better execute the organisation's strategy (Kaplan and Norton, 2001a). An explicit mention of the strategy better facilitates such communication than not mentioning the strategy at all, which is why most strategy map frameworks have explicitly mentioned them.

\subsubsection{Strategic themes}

Principle 2: A strategy map needs to incorporate strategic themes

Strategic themes are an emerging concept in management (accounting) literature where, to date, little research has been done, although it has several claimed benefits. Strategic themes are the building blocks or pillars of an organisation's strategy and provide a way forward to 
segment the strategy into a few high-level categories (Kaplan and Norton, 2001a, 2004b). For example, DuPont's Engineering Polymers division's strategy is built around five strategic themes: operational excellence, supply and service, manage the portfolios of products and applications, customer management, and new business design (Kaplan and Norton, 2006a, p. 104). Through breaking down the strategy into a few high-level categories, strategic themes help executives to plan and manage key elements of a strategy separately, yet in a cohesive way (Kaplan and Norton, 2008b).

Due to the above-claimed benefits of strategic themes, especially to facilitate strategy implementation, most strategy map frameworks observed have mentioned strategic themes explicitly (e.g., Cugini et al., 2011, p. 273; Kaplan and Norton, 2004b, pp. 123, 246). In practice, the benefit of incorporating strategic themes in strategy maps is also evidential:

In the early years of balanced scorecard implementation, we encouraged full discussion of BSC measures at each strategy management meeting. It soon became apparent that the normal time reserved for a monthly meeting did not permit a full discussion of all the objectives, measures, and initiatives on a strategy map and scorecard. The solution, we discovered, came from the practice of using strategic themes to organize strategy maps: devote most of the meeting to a deep dive into one or two of the strategic themes (Kaplan and Norton, 2008b, p. 74).

Incorporating strategic themes in strategy maps is not only beneficial for commercial organizations but also for non-commercial organizations, as demonstrated by Kaplan and Norton (2006b, p. 108) from their experience of working with the Royal Canadian Mounted Police: "Mapping strategic themes is particularly well suited to the public sector, where organizations have limited political freedom to experiment with structural change".

Principle 3: All important strategic themes need to be mapped either in a single strategy map or in multiple strategy maps

From the above discussion, it is clear that strategic themes are an important part of strategy map frameworks. But this raises another question: How many strategic themes should be incorporated into a strategy map framework? There is no universal answer for this. Most strategy map frameworks observed have incorporated three to five such themes (e.g., Chan, 2009, p. 353; Kaplan and Norton, 2001a, p. 119; 2006a, p. 180). However, this should not be followed strictly. When a strategic theme is included in a strategy map, some other associated items (e.g., strategic objectives), as will be discussed, are also included. If an organisation has a relatively small operation and has only a few strategic themes and a few associated items, a single strategy map may incorporate all strategic themes and their associated items. On the 
other hand, if an organisation has a relatively large operation and a higher number of strategic themes and a higher number of associated items, it may create a separate strategy map for each strategic theme and its associated items. For example, the Royal Canadian Mounted Police (an organisation having a budget in excess of CAD $\$ 2.6$ billion and more than 22,000 employees) had five strategic themes and developed a separate strategy map for each of them (Kaplan and Norton, 2006a). However, it should be noted that a greater number of strategic themes may not equate to greater benefits to organisations; rather, it may cause a lack of strategic focus in an organisation. Accordingly, a few important strategic themes (e.g., five strategic themes in the case of Royal Canadian Mounted Police) may ensure a clear strategic focus in an organisation.

In sum, strategic themes are an important element of strategy maps, and all important strategic themes should be mapped either in a single strategy map or in multiple strategy maps.

\subsubsection{Key focus areas}

Principle 4: A strategy map needs to incorporate key focus areas

An organisation can measure its performance in many areas, such as profitability, cost, customer, supplier, innovation, and so on. But it does not make sense for an organisation to measure its performance in all those areas; rather, it needs to focus on a few key areas of performance in relation to its strategy, which has been termed as 'key focus areas' (KFAs).

As KFAs are the vital few areas of performance that an organisation needs to focus on to deliver its strategy, they are considered an integral part of strategy maps. Consequently, most strategy map frameworks observed have mentioned KFAs (e.g., Kaplan and Norton, 2004b, p. 246; 2006a, pp. 88-89). The mapping of KFAs conveys the broader or high-level strategy story of an organisation.

Principle 5: All important key focus areas regarding an organisation's strategy need to be included in a strategy map

Most strategy map frameworks observed have four KFAs - financial, customer, internal, and learning and growth (e.g., Kaplan and Norton, 2004b, pp. 272, 348; 2008b, p. 69). But these four KFAs should not be taken for granted for every organisation's strategy map. Rather, the number and types of KFA to be included in a strategy map framework will depend on an organisation's strategy. For example, in addition to typical four KFAs, the strategy map of Nike Europe included two additional KFAs - sustainability and people (Lohman et al., 2004). This extension was made in order to fit Nike's "mission and strategy" (Lohman et al., 2004, p. 274). 
In the recent past, Nike started several projects to increase the awareness for sustainable growth, and this sustainability KFA in the strategy map represented the interaction between the company and its environment (Lohman et al., 2004). In order to operationalise the sustainability KFA in its strategy map, the company asked itself: "Are we safeguarding the environment?" (Lohman et al., 2004, p. 274). Similarly, the people KFA in the strategy map was intended to assess Nike's organizational health such as employee satisfaction, professional development, and diversity (Lohman et al., 2004). In order to operationalise the people KFA in its strategy map, the company asked itself: "How are we building our organization?" (Lohman et al., 2004, p. 274).

Principle 6: The hierarchical order of key focus areas in a strategy map needs to be in line with an organisation's strategy and structure

The hierarchical order of KFAs is an important consideration in developing strategy maps. Most strategy map frameworks observed have placed financial performance at the top, following customer performance, internal process performance, and learning and growth performance, respectively (e.g., Kaplan and Norton, 2001a, p. 207; 2004b, p. 246). But this typical structure should not be taken for granted; rather, the hierarchical order of KFAs in a strategy map will depend on the organisation's structure and strategy. Commercial organisations that stress shareholder value maximisation typically place financial performance at the top, followed by other performance areas. On the other hand, government and not-forprofit organisations usually do not focus primarily on financial performance; rather, their primary focus remains on other areas of performance (e.g., customers, employees). Accordingly, they may, for example, place customer performance at the top, followed by other performance areas. Thus, the hierarchy of KFAs in their strategy maps should be different from the typical strategy map framework that puts financial performance at the top. Kaplan (2009, pp. 1262-1263) also proclaims this:

Since financial success is not their primary objective, NPSEs [not-profit and public sector enterprises] cannot use the standard architecture of the balanced scorecard strategy map [emphasis added], where financial objectives are the ultimate, high-level outcomes to be achieved.

Further, two KFAs can be placed in a parallel position and do not necessarily need to be placed in an upward-downward direction, as observed in most strategy map frameworks (e.g., Kaplan and Norton, 2004a, p. 12; 2006b, p. 106). If an organisation's strategy demands that similar attention is paid to, for example, financial and customer performance areas, both of these KFAs should be placed in a parallel position in the strategy map framework. Strategic stakeholder 
management theory suggests that commercial organizations may also place a joint focus on financial and/or other areas of performance (e.g., customers, employees, product quality, etc.) as long as that aligns with their strategy (e.g., for higher economic performance, a source of competitive advantage) (see Berman et al., 1999; Harrison et al., 2010). The idea of a parallel position of two or more KFAs may be more appropriate for public and not-for-profit organisations. In contrast to commercial organizations, these organizations generally try to solve extremely complex problems (Kaplan and Norton, 2006a), where at times, some objectives may complement each other, but at other times, some objectives may conflict with each other (Sundin et al., 2010). As long as the organisation has a strategic need to place the same level of focus on two or more KFAs, they should be placed in a parallel position in the strategy map. Kaplan (2009, p. 1263) also affirms this, while mentioning the future direction of strategy maps:

One additional modification is required ... [in the strategy map regarding NPSEs (nonprofit and public sector enterprises)]. Donors or taxpayers provide the financial resources - they pay for the service - while another group, the citizens and beneficiaries, receive the service. Both constituents and resource suppliers should be placed at the top of an NPSE strategy map. [Emphasis added]

Taken together, KFAs are an important part of strategy map frameworks, and the number of KFAs to be incorporated should depend on an organisation's strategy. Also, the hierarchical order of KFAs can be in any order (e.g., upward-downward direction) and can be in a parallel position, depending on the organisation's strategy and structure.

\subsubsection{Strategic objectives}

\section{Principle 7: A strategy map needs to include strategic objectives}

Following the development of strategic themes, organisations develop strategic objectives regarding each of those themes (Kaplan and Norton, 2006a). Strategic objectives are more precise and are specific parts of strategic themes, and communicate to employees how a particular theme should be interpreted in the organisational context (Kaplan and Norton, 2006a). For example, some of the strategic objectives under the strategic theme operational excellence of DuPont's Engineering Polymers division were to minimise operating cost, achieve optimum asset utilisation, drive polymer process robustness (Kaplan and Norton, 2006a, p. 105).

Strategic objectives form an integral part of strategy maps. In fact, it is the strategic objectives linked throughout the strategy map that show how an organisation's strategy will be 
implemented (Kaplan, 2009). Without showing how different strategic objectives create value to achieve the organisation's strategy, a strategy map will remain incomplete (Kaplan and Norton, 2004b). Hence, almost all strategy map frameworks observed have strategic objectives.

Principle 8: All important strategic objectives need to be mapped either in a single strategy map or in multiple strategy maps

Another issue around strategic objectives' incorporation into strategy maps has to do with the question: How many strategic objectives should be incorporated? There is no definitive answer to this. Although most strategy map frameworks observed mention 16-20 strategic objectives (e.g., Kaplan and Norton, 2004b, pp. 348, 400), this should not be followed blindly. An organisation with a small operation may have only a few strategic objectives, and a single strategy map may incorporate all of them. On the other hand, an organisation with a large operation may have a higher number of strategic objectives, and it may create multiple strategy map frameworks to accommodate them. This is what the Royal Canadian Mounted Police does (Kaplan and Norton, 2006b).

In sum, strategic objectives are fundamental to strategy maps, and all important strategic objectives should be mapped either in a single strategy map or in multiple strategy maps.

\subsubsection{Timeline dimension}

\section{Principle 9: A strategy map needs to incorporate timeline dimension}

Understanding time dimension in strategy implementation is crucial, since actions take time to yield desired results (Ancona et al., 2001). Although the pioneers of BSC and strategy maps assert that improvement in leading indicators will improve lagging indicators (Kaplan and Norton, 2001a, 2004b), they have largely remained silent about the time lag between various efforts and their effects (Nørreklit, 2000, 2003).

To date, no practical strategy map framework observed explicitly considers timeline dimension. Nørreklit (2000, p. 71) notes that "if a cause-and-effect relationship requires a time lag between cause and effect, then it is problematic that the time dimension is not part of the scorecard". Accordingly, the inclusion of a timeline dimension in strategy maps can be a worthy consideration. Kaplan (2009, p. 1268) acknowledges that the absence of a time dimension in the strategy map is a developmental limitation:

Strategy maps still represent a highly-aggregated view of causal relationships among strategic objectives. In order to make strategy maps more visually appealing to 
managers and employees, we have simplified the causal relationships assumed within the strategy map ... A detailed systems dynamics model would incorporate causal linkages that have estimates of magnitude and time delay ... [Emphasis added]

That said, having an accurate understanding of a time lag is hard due to several factors, such as the lack of theories and methodologies to measure complex temporal phenomena (Ancona et al., 2001), the lack of a tacit understanding about how temporal structures shape and are shaped within an organizational context (Orlikowski and Yates, 2002), and the existence of numerous ceteris paribus conditions that are nearly impossible to control in natural settings (Malina et al., 2007).

Although it may not be possible to articulate an exact time lag, mentioning a tentative time lag in a strategy map has several potential benefits. Psychology literature suggests that providing expected time frame information of causal relations in question guides individuals to choose appropriate actions within a strategic context (Hagmayer and Waldmann, 2002). Recent accounting research also suggests that explicit mention of possible timeline information in strategy maps ensures decision makers' awareness about the planned time frame for expected results, which, in turn, improves their performance evaluation decision making (Bartlett et al., 2013; Johnson et al., 2014).

Based on the above discussion, it seems worthy to explicitly mention timeline dimension in strategy maps. At the outset, organisations can mention their best-estimated timeline to implement various parts of their strategies. Later, when things will be clearer with the passage of time, organisations can revise the expected timeline as required - a theme grounded in the concept of 'time-based organisational improvisation' suggesting organisations understand the complex dimension of time as it unfolds (Crossan et al., 2005).

\subsubsection{Directional arrows}

\section{Principle 10: A strategy map needs to include directional arrows}

Directional arrows are one of the most used symbols in academia as well as in practice, which can be rooted in psychology literature, which suggests that when people are given directional stimuli (e.g., directional arrows), it increases their causal properties learning significantly through building a more accurate mental representation of the situation (Waldmann et al., 1995).

Similarly, in a strategy map framework, directional arrows help decision makers to build more accurate and comprehensive mental models of complex relationships between several 
temporally separated actions and their expected outcomes (Banker et al., 2011). That is why almost all strategy map frameworks observed have directional arrows.

Principle 11: Directional arrows regarding key focus areas in a strategy map need to correspond to an organisation's strategic context

In strategy maps, directional arrows should indicate how different KFAs are linked to each other. Most strategy map frameworks observed show unidirectional arrows amongst KFAs, for example, learning and growth performance $\rightarrow$ internal process performance $\rightarrow$ customer performance $\rightarrow$ financial performance (e.g., Kaplan and Norton, 2001a, p. 101; 2006a, p. 235).

But the relation amongst KFAs may not necessarily be unidirectional. For example, a higher number of $R \& D$ (research and development) activities may be necessary to obtain a satisfactory financial result, and reciprocally, a satisfactory financial result may also be necessary to support a higher number of $R \& D$ activities. This view is also supported by recent research that shows relations amongst performance measurement variables vary; at times, some may have unidirectional relations, and at other times, some may have reciprocal relations (Malina et al., 2007; Nørreklit, 2000).

Further, it is not necessary for a KFA to have a direct relationship with only one KFA; rather, a KFA can have a direct relationship with more than one KFA, as long as they are aligned with the organisation's strategic context. For example, the strategy map frameworks in Kaplan and Norton (2004b, p. 348) and Kaplan and Norton (2006b, p. 106) show that some strategic objectives about internal performance have direct relationships with strategic objectives about customer performance, while some others have direct relationships with strategic objectives regarding financial performance. That is, in those cases, internal performance has a direct relationship with both customer performance and financial performance.

Overall, the relation between two KFAs can be unidirectional, reciprocal, or any other type. Further, one KFA may have a direct relationship with more than one KFA.

Principle 12: Directional arrows need to be there for all strategic objectives mentioned in a strategy map, showing both inter-and intra-relationships amongst strategic objectives

Showing how different strategic objectives are linked to each other is fundamental to strategy map frameworks (Kaplan and Norton, 2004b, 2006a). That is why almost all strategy map frameworks observed have directional arrows regarding strategic objectives. When using directional arrows to indicate the relationships amongst strategic objectives, one should be 
cautious about four issues. First, directional arrows should be there to indicate not only the inter-relationships (i.e., vertical relationships) amongst strategic objectives across different KFAs (e.g., Kaplan and Norton, 2004b, p. 368), but also the intra-relationships (i.e., horizontal relationships) amongst strategic objectives (e.g., Kaplan and Norton, 2004b, p. 204).

Second, directional arrows should be there for all strategic objectives mentioned in a strategy map. Some strategy map frameworks observed show directional arrows regarding some strategic objectives while leaving others without any directional arrow (e.g., Kaplan and Norton, 2001a, p. 207; 2004b, pp. 229, 363). This approach does not provide a complete picture, since strategic objectives for which no directional arrow has been used seem to stand alone from the rest of the strategic objectives. It may confuse users about what the relation is amongst those no-directional-arrow-used strategic objectives and between them and the rest. Strategy maps that show directional arrows regarding all strategic objectives (e.g., Kaplan and Norton, 2004b, p. 368) depict a clearer picture.

Third, directional arrows regarding KFAs should not be used as a substitute for directional arrows concerning strategic objectives. Some strategy map frameworks observed have shown almost no directional arrows regarding strategic objectives; rather, they have shown them only in relation to KFAs (e.g., Kaplan and Norton, 2004b, pp. 400, 407, 432). This approach is also flawed. Generally, regarding a KFA, there remains more than one strategic objective. For example, two KFAs - employee performance and internal process performance - each have three strategic objectives. On the surface, it is understood that an improved employee performance may result in an improved internal process performance. But it is not necessary that all three strategic objectives regarding employee performance also influence all three strategic objectives concerning internal process performance. Rather, the inter-relationship amongst strategic objectives between two KFAs may vary. Further, there may (not) have been any intra-relationship amongst strategic objectives within a KFA. This complete picture remains unavailable when directional arrows are used only in relation to KFAs, as opposed to strategic objectives.

Fourth, directional arrows in relation to strategic objectives should be in the same direction as that of KFAs. For example, if the relation between two KFAs is unidirectional, their associated strategic objectives should not show any reciprocal relation amongst themselves, and vice versa. Mapping of KFAs conveys the high-level story of the organisation's strategy implementation, whereas mapping strategic objectives convey a more precise story of strategy 
implementation. It is quite logical that the high-level strategy story and the more precise strategy story should agree with each other. Therefore, if the pattern of directional arrows between KFAs and that of strategic objectives are in contradiction, it can be argued logically that either of them is not appropriate.

Principle 13: A strategy map needs to include directional arrows in relation to key focus areas and strategic objectives and strategy/mission/vision

As strategy maps facilitate strategy implementation, there should be directional arrows to show explicitly how the strategy is linked to KFAs and strategic objectives. Usually, KFAs (and associated strategic objectives) that are placed at the top of the strategy map assume a direct relationship with the strategy. Therefore, if a single KFA remains at the top, a directional arrow (headed towards the strategy) may be used in between this KFA and the strategy (e.g., Kaplan and Norton, 2004b, p. 8). Also, if two KFAs remain parallel at the top, directional arrows towards the strategy may originate from both KFAs (e.g., Kaplan and Norton, 2004b, p. 8). The same rule applies in the case of using directional arrows between the top strategic objectives and strategy (e.g., Cugini et al., 2011, p. 273; Kaplan and Norton, 2004b, p. 229).

\subsubsection{Performance markers}

Principle 14: Performance markers need to be added with all directional arrows in relation to strategic objectives in a strategy map

As mentioned already, using directional arrows helps to communicate explicitly that triggering actions in relation to a certain strategic objective will affect another certain strategic objective, which, in turn, will affect another certain strategic objective. However, such communication still remains incomplete, since using only directional arrows does not answer the question: What would be the nature of such effect?

Consider two strategic objectives, where A is around customer satisfaction and B is around accounts receivable. The directional arrow $\mathrm{A} \longrightarrow \mathrm{B}$ indicates that customer satisfaction will affect accounts receivable, but does not say anything about the very nature of the relationship between the two objectives. The nature of their relationship may be that an increase in customer satisfaction will help to decrease accounts receivable. If a performance marker (e.g., '+', '-') is added with the directional arrow, the nature of the expected effect becomes precise: $\mathrm{A} \longrightarrow$ $(-)$ B. 
Performance markers communicate the nature of the expected outcome effect precisely to the decision makers. Psychology literature suggests that providing more precise knowledge about the outcome effect improves individuals' judgement and other decision-making capabilities through reducing their cognitive difficulties (Mitchell and Kalb, 1981; Fischhoff and Beyth, 1975). Such a precise knowledge of the outcome effect also facilitates users to identify and take precise actions towards the desired outcome (Ritov and Baron, 1995).

Despite such claimed benefits, performance markers are a rare feature in strategy map frameworks observed. In fact, performance markers have received so far very limited attention in the accounting literature. One notable exception is Cardinaels and van Veen-Dirks (2010), who find that providing performance markers within a BSC framework increases decision makers' attention towards activities (i.e., measures) that otherwise would be overlooked. This finding suggests that adding performance markers with directional arrows regarding strategic objectives in strategy maps can draw users' attention to required actions to achieve desired outcomes, which would not have been possible otherwise. Consequently, it seems worthwhile to add performance markers throughout all directional arrows in relation to strategic objectives in a strategy map.

A summary of strategy map features and principles is provided in Table 1 .

Table 1: A summary of strategy map features and principles

\begin{tabular}{|c|c|c|c|}
\hline Features & Principles & $\begin{array}{l}\text { Empirical } \\
\text { research }\end{array}$ & $\begin{array}{l}\% \text { of strategy } \\
\text { maps } \\
\text { reviewed } \\
\text { with features }\end{array}$ \\
\hline $\begin{array}{l}\text { Strategy, } \\
\text { mission, } \\
\text { and/or vision }\end{array}$ & $\begin{array}{l}\text { 1. A strategy map needs to } \\
\text { incorporate strategy, mission, } \\
\text { and/or vision statement }\end{array}$ & None & $92 \%$ \\
\hline \multirow[t]{2}{*}{$\begin{array}{l}\text { Strategic } \\
\text { themes }\end{array}$} & $\begin{array}{l}\text { 2. A strategy map needs to } \\
\text { incorporate strategic themes }\end{array}$ & \multirow[t]{2}{*}{ None } & \multirow[t]{2}{*}{$89 \%$} \\
\hline & $\begin{array}{l}\text { 3. All important strategic themes } \\
\text { need to be mapped by either in a } \\
\text { single strategy map or in multiple } \\
\text { strategy maps }\end{array}$ & & \\
\hline \multirow[t]{2}{*}{$\begin{array}{l}\text { Key focus } \\
\text { areas }\end{array}$} & $\begin{array}{l}\text { 4. A strategy map needs to } \\
\text { incorporate key focus areas }\end{array}$ & \multirow[t]{2}{*}{ None } & \multirow[t]{2}{*}{$96 \%$} \\
\hline & $\begin{array}{l}\text { 5. All important key focus areas in } \\
\text { relation to an organisation's strategy } \\
\text { need to be included in a strategy } \\
\text { map }\end{array}$ & & \\
\hline
\end{tabular}




\begin{tabular}{|c|c|c|c|}
\hline Features & Principles & $\begin{array}{l}\text { Empirical } \\
\text { research }\end{array}$ & $\begin{array}{l}\text { \% of strategy } \\
\text { maps } \\
\text { reviewed } \\
\text { with features }\end{array}$ \\
\hline & $\begin{array}{l}\text { 6. The hierarchical order of key } \\
\text { focus areas in a strategy map needs } \\
\text { to be in line with an organisation's } \\
\text { strategy and structure }\end{array}$ & & \\
\hline \multirow[t]{2}{*}{$\begin{array}{l}\text { Strategic } \\
\text { objectives }\end{array}$} & $\begin{array}{l}\text { 7. A strategy map needs to include } \\
\text { strategic objectives }\end{array}$ & \multirow[t]{2}{*}{ None } & \multirow[t]{2}{*}{$98 \%$} \\
\hline & $\begin{array}{l}\text { 8. All important strategic objectives } \\
\text { need to be mapped either in a single } \\
\text { strategy map or in multiple strategy } \\
\text { maps }\end{array}$ & & \\
\hline $\begin{array}{l}\text { Timeline } \\
\text { dimensions }\end{array}$ & $\begin{array}{l}\text { 9. A strategy map needs to } \\
\text { incorporate timeline dimension }\end{array}$ & $\begin{array}{l}\text { (Bartlett } \text { et al., } \\
\text { 2013; Johnson } \text { et } \\
\text { al., 2014) }\end{array}$ & $1 \%$ \\
\hline \multirow[t]{4}{*}{$\begin{array}{l}\text { Directional } \\
\text { arrows }\end{array}$} & $\begin{array}{l}\text { 10. A strategy map needs to include } \\
\text { directional arrows }\end{array}$ & \multirow{4}{*}{$\begin{array}{l}\text { (Farrell et al., } \\
\text { 2012; Humphreys } \\
\text { and Trotman, } \\
\text { 2011) }\end{array}$} & \multirow[t]{4}{*}{$99 \%$} \\
\hline & $\begin{array}{l}\text { 11. Directional arrows regarding } \\
\text { key focus areas in a strategy map } \\
\text { need to correspond to an } \\
\text { organisation's strategic context }\end{array}$ & & \\
\hline & $\begin{array}{l}\text { 12. Directional arrows need to be } \\
\text { there for all strategic objectives } \\
\text { mentioned in a strategy map, } \\
\text { showing both inter- and intra- } \\
\text { relationships amongst strategic } \\
\text { objectives }\end{array}$ & & \\
\hline & $\begin{array}{l}\text { 13. A strategy map needs to include } \\
\text { directional arrows in relation to key } \\
\text { focus areas and strategic objectives } \\
\text { and strategy/mission/vision }\end{array}$ & & \\
\hline $\begin{array}{l}\text { Performance } \\
\text { markers }\end{array}$ & $\begin{array}{l}\text { 14. Performance markers need to be } \\
\text { added with all directional arrows in } \\
\text { relation to strategic objectives in a } \\
\text { strategy map }\end{array}$ & None & $1 \%$ \\
\hline
\end{tabular}

To visualise all 14 principles across seven features, Figure 1 provides a hypothetical example of a strategy map framework. In this hypothetical strategy map, it is assumed that the current strategy of the firm is sustained profitable business through product innovation leadership. Product innovation can encompass new product development, product-line extensions, product improvements and style changes (Heany, 1983). Product innovation is vital not only for a firm's survival in the market but also to allow a firm to successfully compete and flourish in 
the face of emerging adverse and fluctuating business conditions (Dougherty, 1992; Eisenhardt and Tabrizi, 1995). 


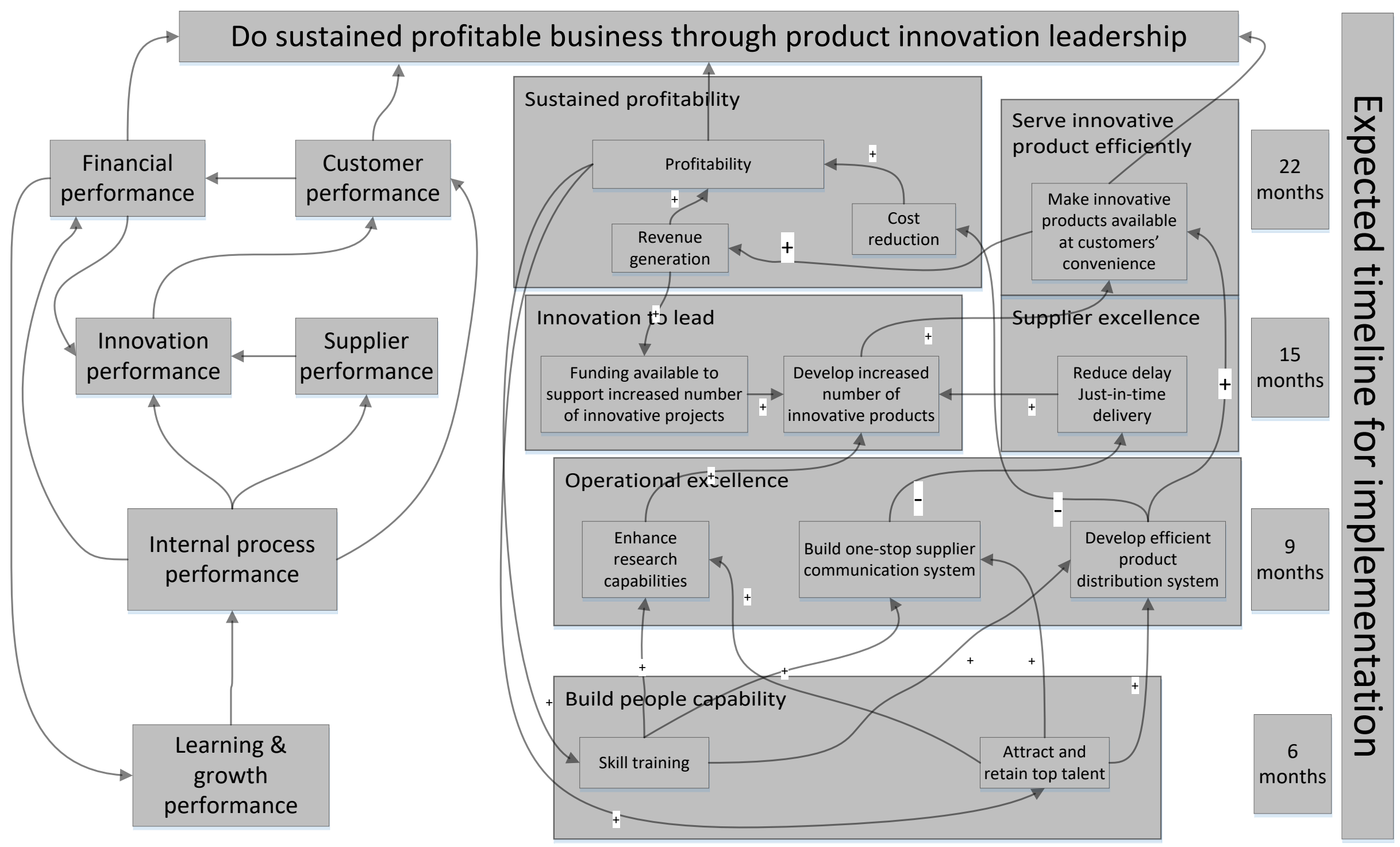

Figure 1 A hypothetical strategy map framework containing 14 principles across seven features 


\section{Conclusion}

This study aims to synthesise the prior literature on strategy maps to develop a practitioner's guide to the design of strategy maps. By reviewing 41 publications on strategy maps, including 333 strategy map frameworks, as well as the general accounting, management, and psychology literature, the current study develops 14 principles across seven features for designing strategy maps. This study contributes to the strategy map literature by serving as a 'one-stop-shop' for both practitioners and researchers seeking a state-of-the-art overview of strategy map design features and principles.

This study finds that most strategy map frameworks available in the existing literature depict the generic strategy map architecture (e.g., incorporation of only financial, customer, internal business process, and learning and growth performance areas, putting financial performance at the top). There is a body of literature, though often overlooked, which suggests that generic strategy map framework is not suitable in all cases. This literature also provides some guidance about what sorts of modifications may be necessary in strategy map frameworks in relation to different contexts (e.g., in the case of commercial, public, and not-for-profit organisational structures) (see e.g., principles 5, 6, and 11). However, this literature is less highlighted and little recognised in the overall strategy map literature. As a result, naive users of strategy maps are more susceptible to falling prey to the problems associated with the adoption of a generic strategy map framework. The current study thus contributes to overcoming this issue by highlighting the literature for developing customised strategy maps.

The current study offers several future research avenues. First, most literature on strategy maps is normative (e.g., Kaplan and Norton, 2004b, 2006a), with little empirical research (e.g., Cheng and Coyte, 2014; Humphreys and Trotman, 2011). Existing empirical research has examined the effectiveness of an overall strategy map (see Banker et al., 2011; Cheng and Coyte, 2014; Cugini et al., 2011; Humphreys and Trotman, 2011; Rompho, 2012), rather than examining the effectiveness of individual design features and/or principles of strategy maps (see Table 1). To date, only two strategy map features have received attention from researchers: timeline dimension and directional arrows (i.e., causal linkages) (see Table 1). Accordingly, we know little about which strategy map features and/or principles are relatively more or less important. Further, due to a lack of empirical research, we have little understanding about whether, to be effective, a strategy map needs to incorporate all 14 design principles across seven design features, or if a few of them will be sufficient. Future research investigating these 
issues could substantially improve our current understanding of strategy map design features and principles.

The second avenue for future research would be the overall testing of hypotheses underlying a strategy map. Organizations can develop a strategy map based on an ex-ante hypothesis of the nature of the relation between different variables or based on an ex-post validation of the hypothesis. However, it is little known whether and how organizations test hypotheses underlying their strategy maps and thereby revise the strategy (maps).

Third, a strategy map can be built on a combination of cause-and-effect, finality, and/or logical relations, as opposed to only cause-and-effect relations (Islam, 2016; Malina et al., 2007). Although Kaplan and Norton have depicted their strategy maps based on cause-and-effect relations, it would interesting to see whether and how the design framework of finality- and/or logical-relation-based strategy maps would be different from the cause-and-effect relationbased strategy maps.

Fourth, some scholars view strategy as managing organizational contradictions and ambiguity (e.g., McCabe, 2010). Therefore, a strategy map is also expected to face these contradictions and ambiguity. However, little empirical research exists on whether and how a strategy map contributes to managing such contradictions and ambiguity.

Finally, we know that a managerial tool (e.g., the BSC) can have both positive and negative effects (Hoque, 2014), and that incompleteness of such a tool at times can be considered problematic and other times non-problematic (Islam et al., 2017; Jordan and Messner, 2012). However, the strategy map literature seems to document only the beneficial effects of strategy maps, neglecting potential negative effects. This literature also does not address whether and when incompleteness of a strategy map can be considered problematic and non-problematic. Future researchers could investigate these issues in greater detail to help managers to better understand the boundary conditions of strategy maps.

Notes:

1. The Chartered Global Management Accountant (CGMA) includes strategy maps as one of the four essential management tools for strategic planning and execution (see http://www.cgma.org/Resources/Tools/essential-tools/Pages/list.aspx, accessed 20 June 2015). Further, several consulting firms use strategy maps to facilitate their 
clients' strategy execution (e.g., http://www.excitant.co.uk/resources/whitepapers/strategy-maps-and-strategy-mapping, accessed 20 June 2015).

Appendix A: Publications on strategy maps reviewed and number of strategy map frameworks observed (only authors and year are listed for some publications, whose details can be found in the 'references' section)

Number of

Number Publications strategy map frameworks

1 Abernethy, M. A., Horne, M., Lillis, A. M., Malina, M. A., \& Selto, F. H. (2005). A multi-method approach to building causal performance maps from expert knowledge. Management Accounting Research, 16(2), 135-155.

2 Banker, R. D., Chang, H., \& Pizzini, M. (2011).

Banker, R. D., Chang, H., \& Pizzini, M. J. (2004).

Bartlett, G., Johnson, E., \& Reckers, P. (2013).

Busco, C., \& Quattrone, P. (2015). Exploring How the Balanced Scorecard

Engages and Unfolds: Articulating the Visual Power of Accounting Inscriptions. Contemporary Accounting Research, 32(3), 1236-1262.

6 Busco, C., Quattrone, P., \& Riccaboni, A. (2007). Management accounting: Issues in interpreting its nature and change. Management Accounting Research, 18(2), 125-149.

7 Carmona, S., lyer, G., \& Reckers, P. M. J. (2011). The impact of strategy communications, incentives and national culture on balanced scorecard implementation. Advances in Accounting, 27(1), 62-74.

8 Chan, Y.-C. L. (2009).

$9 \quad$ Cheng, M. M., \& Coyte, R. (2014).

10 Cheng, M. M., \& Humphreys, K. A. (2012).

11 Cokins, G. (2010). The promise and perils of the balanced scorecard. Journal of Corporate Accounting \& Finance, 21(3), 19-28.

12 Cugini, A., Michelon, G., \& Pilonato, S. (2011).

13 Farrell, A. M., Kadous, K., \& Towry, K. L. (2012). training affects organizational performance: the case of a Greek bank. International Journal of Human Resource Management, 22(14), 2892-2923.

15 González, J. M. H., Calderón, M. Á., \& González, J. L. G. (2012). The alignment of managers' mental models with the balanced scorecard strategy map. Total Quality Management \& Business Excellence, 23(5-6), 613-628.

16 Huelsbeck, D. P., Merchant, K. A., \& Sandino, T. (2011). On testing business models. The Accounting Review, 86(5), 1631-1654. 
17 Humphreys, K. A., \& Trotman, K. T. (2011). The Balanced Scorecard: The Effect 1 of Strategy Information on Performance Evaluation Judgments. Journal of Management Accounting Research, 23, 81-98.

18 Johnson, E. N., Reckers, P. M. J., \& Bartlett, G. D. (2014).

19 Joseph, G. (2009). Mapping, Measurement and Alignment of Strategy using the Balanced Scorecard: The Tata Steel Case. Accounting Education, 18(2), 117-130.

20 Joseph, G., \& George, A. (2011).

Kaplan, R. S. (2009).

26 Kaplan, R. S., \& Norton, D. P. (2004a).

Kaplan, R. S., \& Norton, D. P. (2004b). effect of positive and negative performance on the relative weighting of strategically and non-strategically linked balanced scorecard measures. Behavioral Research in Accounting, 24(2), 133-151.

33 Lawson, R., Stratton, W., \& Hatch, T. (2005). Achieving strategy with scorecarding. Journal of Corporate Accounting \& Finance, 16(3), 63-68.

34 Lowe, D. J., Carmona-Moreno, S., \& Reckers, P. M. J. (2011). Strategy Tools: Producing Strategic Knowledge in Workshops. British Journal of Management, 26, S48-S66.

37 Rompho, N. (2012).

38 Sundin, H., Granlund, M., \& Brown, D. A. (2010).

39 Tayler, W. B. (2010). 


\section{References}

Adler, R. W. (2011), "Performance management and organizational strategy: How to design systems that meet the needs of confrontation strategy firms", The British Accounting Review, Vol. 43 No. 4, pp. 251-263.

Ancona, D. G., Goodman, P. S., Lawrence, B. S. and Tushman, M. L. (2001), "Time: A new research lens", Academy of Management Review, Vol. 26 No. 4, pp. 645-663.

Atkinson, A. A., Balakrishnan, R., Booth, P., Cote, J. M., Groot, T., Malmi, T., Roberts, H., Enrico, Uliana and Wu, A. (1997), "New directions in management accounting research", Journal of Management Accounting Research, Vol. 9, pp. 79-108.

Banker, R. D., Chang, H. and Pizzini, M. (2011), "The judgmental effects of strategy maps in balanced scorecard performance evaluations", International Journal of Accounting Information Systems, Vol. 12 No. 4, pp. 259-279.

Banker, R. D., Chang, H. and Pizzini, M. J. (2004), "The balanced scorecard: Judgmental effects of performance measures linked to strategy", The Accounting Review, Vol. 79 No. 1, pp. 1-23.

Bartlett, G., Johnson, E. and Reckers, P. (2013), "Accountability and role effects in balanced scorecard performance evaluations when strategy timeline is specified", European Accounting Review, Vol. 23 No. 1, pp. 143-165.

Berman, S. L., Wicks, A. C., Kotha, S. and Jones, T. M. (1999), "Does stakeholder orientation matter? The relationship between stakeholder management models and firm financial performance", Academy of Management Journal, Vol. 42 No. 5, pp. 488-506.

Cardinaels, E. and van Veen-Dirks, P. M. G. (2010), "Financial versus non-financial information: The impact of information organization and presentation in a Balanced Scorecard", Accounting, Organizations and Society, Vol. 35 No. 6, pp. 565-578.

Chan, Y.-C. L. (2009), "How strategy map works for Ontario's health system", International Journal of Public Sector Management, Vol. 22 No. 4, pp. 349-363.

Cheng, M. M. and Coyte, R. (2014), "The effects of incentive subjectivity and strategy communication on knowledge-sharing and extra-role behaviours", Management Accounting Research, Vol. 25 No. 2, pp. 119-130.

Cheng, M. M. and Humphreys, K. A. (2012), "The differential improvement effects of the strategy map and scorecard perspectives on managers' strategic judgments", The Accounting Review, Vol. 87 No. 3, pp. 899-924.

Chenhall, R. H. (2005), "Integrative strategic performance measurement systems, strategic alignment of manufacturing, learning and strategic outcomes: An exploratory study", Accounting, Organizations and Society, Vol. 30 No. 5, pp. 395-422.

Collis, D. J. and Rukstad, M. G. (2008), "Can You Say What Your Strategy Is?", Harvard Business Review, Vol. 86 No. 4, pp. 82-90.

Crossan, M., Cunha, M. P. E., Vera, D. and Cunha, J. (2005), "Time and organizational improvisation", Academy of Management Review, Vol. 30 No. 1, pp. 129-145.

Cugini, A., Michelon, G. and Pilonato, S. (2011), "Performance measurement in academic departments: the strategy map approach", Public Money \& Management, Vol. 31 No. 4, pp. 271-278.

Dougherty, D. (1992), "Interpretive barriers to successful product innovation in large firms", Organization science, Vol. 3 No. 2, pp. 179-202.

Eisenhardt, K. M. and Tabrizi, B. N. (1995), "Accelerating Adaptive Processes: Product Innovation in the Global Computer Industry", Administrative Science Quarterly, Vol. 40 No. 1, pp. 84-110.

Farrell, A. M., Kadous, K. and Towry, K. L. (2012), "Does the communication of causal linkages improve employee effort allocations and firm performance? An experimental investigation", Journal of Management Accounting Research, Vol. 24 No. 1, pp. 77-102.

Fischhoff, B. and Beyth, R. (1975), "I knew it would happen: Remembered probabilities of oncefuture things", Organizational Behavior and Human Performance, Vol. 13 No. 1, pp. 1-16. 
Hagmayer, Y. and Waldmann, M. R. (2002), "How temporal assumptions influence causal judgments", Memory \& Cognition, Vol. 30 No. 7, pp. 1128-1137.

Harrison, J. S., Bosse, D. A. and Phillips, R. A. (2010), "Managing for stakeholders, stakeholder utility functions, and competitive advantage", Strategic Management Journal, Vol. 31 No. 1, pp. 5874.

Heany, D. F. (1983), "Degrees of product innovation", Journal of Business Strategy, Vol. 3 No. 4, pp. 314.

Hoque, Z. (2014), "20 years of studies on the balanced scorecard: Trends, accomplishments, gaps and opportunities for future research", The British Accounting Review, Vol. 46 No. 1, pp. 33-59.

Humphreys, K. A. and Trotman, K. T. (2011), "The Balanced Scorecard: The Effect of Strategy Information on Performance Evaluation Judgments", Journal of Management Accounting Research, Vol. 23, pp. 81-98.

Islam, S. (2016), "Reconceptualizing the notion of relations underlying performance measurement models: Implications for research", Pacific Accounting Review, Vol. 28 No. 4, pp. 411-418.

Islam, S., Adler, R. and Northcott, D. (2017), "Managerial attitudes towards the incompleteness of performance measurement systems", Qualitative Research in Accounting \& Management, advanced online publications https://doi.org/10.1108/QRAM-10-2017-0106

Johnson, E. N., Reckers, P. M. J. and Bartlett, G. D. (2014), "Influences of Timeline and Perceived Strategy Effectiveness on Balanced Scorecard Performance Evaluation Judgments", Journal of Management Accounting Research, Vol. 26 No. 1, pp. 165-184.

Jordan, S. and Messner, M. (2012), "Enabling control and the problem of incomplete performance indicators", Accounting, Organizations and Society, Vol. 37 No. 8, pp. 544-564.

Joseph, G. and George, A. (2011), "An Integrative Approach to Planning and Control using a Stakeholder-Based Knowledge Management System", Journal of Applied Management Accounting Research, Vol. 9 No. 1, pp. 1-19.

Kaplan, R. S. (2009), "Conceptual Foundations of the Balanced Scorecard", in Chapman, C. S., Hopwood, A. G. and Shields, M. D. (Eds.), Handbooks of Management Accounting Research, Elsevier, Oxford, UK, pp. 1253-1269.

Kaplan, R. S. and Norton, D. P. (1992), "The balanced scorecard - Measures that drive performance", Harvard Business Review, Vol. 70 No. 1, pp. 71-79.

Kaplan, R. S. and Norton, D. P. (2000), "Having trouble with your strategy? Then map it", Harvard Business Review, Vol. 78 No. 5, pp. 167-176.

Kaplan, R. S. and Norton, D. P. (2001a), The Strategy-Focused Organization: How Balanced Scorecard Companies Thrive in the New Business Environment, Harvard Business School Press, Boston, Massachusetts.

Kaplan, R. S. and Norton, D. P. (2001b), "Transforming the balanced scorecard from performance measurement to strategic management: Part I", Accounting Horizons, Vol. 15 No. 1, pp. 87104.

Kaplan, R. S. and Norton, D. P. (2004a), "The strategy map: guide to aligning intangible assets", Strategy \& Leadership, Vol. 32 No. 5, pp. 10-17.

Kaplan, R. S. and Norton, D. P. (2004b), Strategy Maps: Converting Intangible Assets into Tangible Outcomes, Harvard Business School Press, Boston, Massachusetts.

Kaplan, R. S. and Norton, D. P. (2006a), "Alignment: Using the Balanced Scorecard to Create Corporate Synergies", Harvard Business School Press, Boston, Massachusetts.

Kaplan, R. S. and Norton, D. P. (2006b), "How to implement a new strategy without disrupting your organization", Harvard Business Review, Vol. 84 No. 3, pp. 100-109.

Kaplan, R. S. and Norton, D. P. (2008a), The Executive Premium: Linking Strategy to Operations for Competitive Advantage, Harvard Business School Press, Boston, Massachusetts.

Kaplan, R. S. and Norton, D. P. (2008b), "Mastering the management system", Harvard Business Review, Vol. 86 No. 1, pp. 62-77. 
Langfield-Smith, K. (2005), "What Do We Know about Management Control Systems and Strategy?", in Chapman, C. S. (Ed.), Controlling strategy : management, accounting, and performance measurement, Oxford University Press Oxford, pp. 62-85.

Lohman, C., Fortuin, L. and Wouters, M. (2004), "Designing a performance measurement system: A case study", European Journal of Operational Research, Vol. 156 No. 2, pp. 267-286.

Lowe, D. J., Carmona-Moreno, S. and Reckers, P. M. J. (2011), "The influence of strategy map communications and individual differences on multidimensional performance evaluations", Accounting and Business Research, Vol. 41 No. 4, pp. 375-391.

Malina, M. A., Nørreklit, H. and Selto, F. H. (2007), "Relations among measures, climate of control, and performance measurement models", Contemporary Accounting Research, Vol. 24 No. 3, pp. 935-982.

McCabe, D. (2010), "Strategy-as-power: Ambiguity, contradiction and the exercise of power in a UK building society", Organization, Vol. 17 No. 2, pp. 151-175.

Mitchell, T. R. and Kalb, L. S. (1981), "Effects of outcome knowledge and outcome valence on supervisors' evaluations", Journal of Applied Psychology, Vol. 66 No. 5, pp. 604-612.

Nørreklit, H. (2000), "The balance on the balanced scorecard: A critical analysis of some of its assumptions", Management Accounting Research, Vol. 11 No. 1, pp. 65-88.

Nørreklit, H. (2003), "The Balanced Scorecard: what is the score? A rhetorical analysis of the Balanced Scorecard", Accounting, Organizations and Society, Vol. 28 No. 6, pp. 591-619.

Orlikowski, W. J. and Yates, J. (2002), "It's about Time: Temporal Structuring in Organizations", Organization Science, Vol. 13 No. 6, pp. 684-700.

Ritov, I. and Baron, J. (1995), "Outcome knowledge, regret, and omission bias", Organizational Behavior and Human Decision Processes, Vol. 64 No. 2, pp. 119-127.

Rompho, N. (2012), "An experiment in the usefulness of a strategy map", Measuring Business Excellence, Vol. 16 No. 2, pp. 55-69.

Sundin, H., Granlund, M. and Brown, D. A. (2010), "Balancing multiple competing objectives with a balanced scorecard", European Accounting Review, Vol. 19 No. 2, pp. 203-246.

Tayler, W. B. (2010), "The Balanced Scorecard as a Strategy-Evaluation Tool: The Effects of Implementation Involvement and a Causal-Chain Focus", The Accounting Review, Vol. 85 No. 3, pp. 1095-1117.

Vera-Muñoz, S. C., Shackell, M. and Buehner, M. (2007), "Accountants' usage of causal business models in the presence of benchmark data: A note", Contemporary Accounting Research, Vol. 24 No. 3, pp. 1015-1038.

Waldmann, M. R., Holyoak, K. J. and Fratianne, A. (1995), "Causal models and the acquisition of category structure", Journal of Experimental Psychology: General, Vol. 124 No. 2, pp. 181-206. 